\title{
Service quality of transit and demand-supply forecasting for ride-hailing in the Jakarta Greater Area, Indonesia
}

DOI : 10.36909/jer.14725

Gito Sugiyanto*, Yanto*, Aris Wibowo** and Teguh Wiji Astoto ${ }^{* * *}$

*Civil Engineering Department, Jenderal Soedirman University, Central Java, Indonesia.

${ }^{* *}$ Civil Engineer \& Transport Planner in PT Nur Straits Engineering (NSE) Bandung, Indonesia.

${ }^{* * *}$ Civil Engineer in PT Rekabhumi Segarayasa Bestari, East Java, Indonesia.

Corresponding Author: gito.sugiyanto@unsoed.ac.id.

\begin{abstract}
The extensive use of smartphones by individuals has led innovators to develop applicationbased transportation services. Ride-hailing systems have been extensively operated in more than 600 cities worldwide. With the competition between taxis and ride-hailing, the number of fleets must be regulated. Identifying factors that influence the demand of taxi and ride-hailing and how the quality transit service is very important. The aims of this research are to identify the factors that influence demand for taxis and ride-hailing and the service quality of taxis and ride-hailing service. The study identified socio-demographic and trip characteristics from 949 respondents in the Jakarta Greater area, Indonesia. Respondents interviewed about the waiting time, travel time and travel costs for the origin-destination of trips that are most often done using taxi, ride-hailing, and bus. The service quality of ride-hailing and taxi was analyzed based on the respondent's preferences from an important-performance analysis survey. The forecasting demand of taxi and ride-hailing in the Jakarta Greater area using demand-supply model is 71,660 vehicles. The research findings are that service quality of ride-hailing is better than conventional taxis based on waiting time, travel time and travel cost variable.
\end{abstract}

Key words: Ride-hailing; Taxi; Travel behavior; Demand-supply; Service attribute.

\section{INTRODUCTION}

Application of information and communications technology (ICT) is widely used in the transport sector (Csiszár \& Földes, 2015; Circella \& Mokhtarian, 2017). The emergence of new technologies in transportation systems has greatly impacted personal mobility. One of the 
applications of ICT in transportation is the ride-hailing system, which expanded their operation to more than 600 cities worldwide (Kim et al., 2017). Ride-hailing services are distinguished from traditional mobility options, they match passengers to the nearest driver using specific algorithms (Rayle et al., 2016). The impact after ride-hailing service entered urban mobility, the number of passenger conventional taxis decreased. In New York City, conventional taxi rides reduced $25 \%$ per hour and taxi passengers decreased by 16 million passengers (Brodeur \& Nield, 2018). Uber is a complement for the average transit agency, increasing ridership by 5\% (Hall et al., 2018). Approximately one third of public transportation trips are potentially transferred to ride-hailing service (Oviedo et al., 2020).

The development of the demand model for transit developed after the operation of ride-hailing in several major cities in early 2010. In a previous study, six factors determine the number of taxi pickups and drop-offs: transit access time, population size, median age, percent of population educated beyond bachelor's degree, income per capita, and number of employment opportunities (Gonzales et al., 2014). Chang et al. (2010) using clustering algorithms to predict taxi demand distributions. Moreira-Matias et al. (2012) applied time series techniques to forecast taxi passenger demand. Gong et al. (2016) proposed a machine learning model to predict the number of taxis. Most of these efforts have focused on taxi trip demand, whereas the studies on ride-hailing service demand prediction have been relatively limited.

The aims of this research are to identify the factors that influence demand for taxis and ridehailing and the quality of taxis and ride-hailing service. The novelty of this research is the development of a demand model for the number of taxis and ride-hailing using demand-supply approach and service quality of transit using importance-performance analysis (IPA).

\section{METHODOLOGY}

\section{STUDY AREA AND RESEARCH STAGE}

Location of the study in the Jakarta Greater area, Indonesia consists of nine regions, namely Jakarta Special Province, Bogor City, Bogor Regency, Depok City, Tangerang City, Tangerang 
Regency, South Tangerang City, Bekasi City, and Bekasi Regency. The stages of the research are as follows: literature review, questionnaire design, collecting data, survey (household travel survey, service quality, demand-supply attribute, and importance-performance analysis/IPA, analysis data (IPA of taxi and IPA of ride-hailing, demand supply forecasting, modeling taxi and ride-hailing demand, sensitivity model). The stages of the research can be seen in Figure 1 .

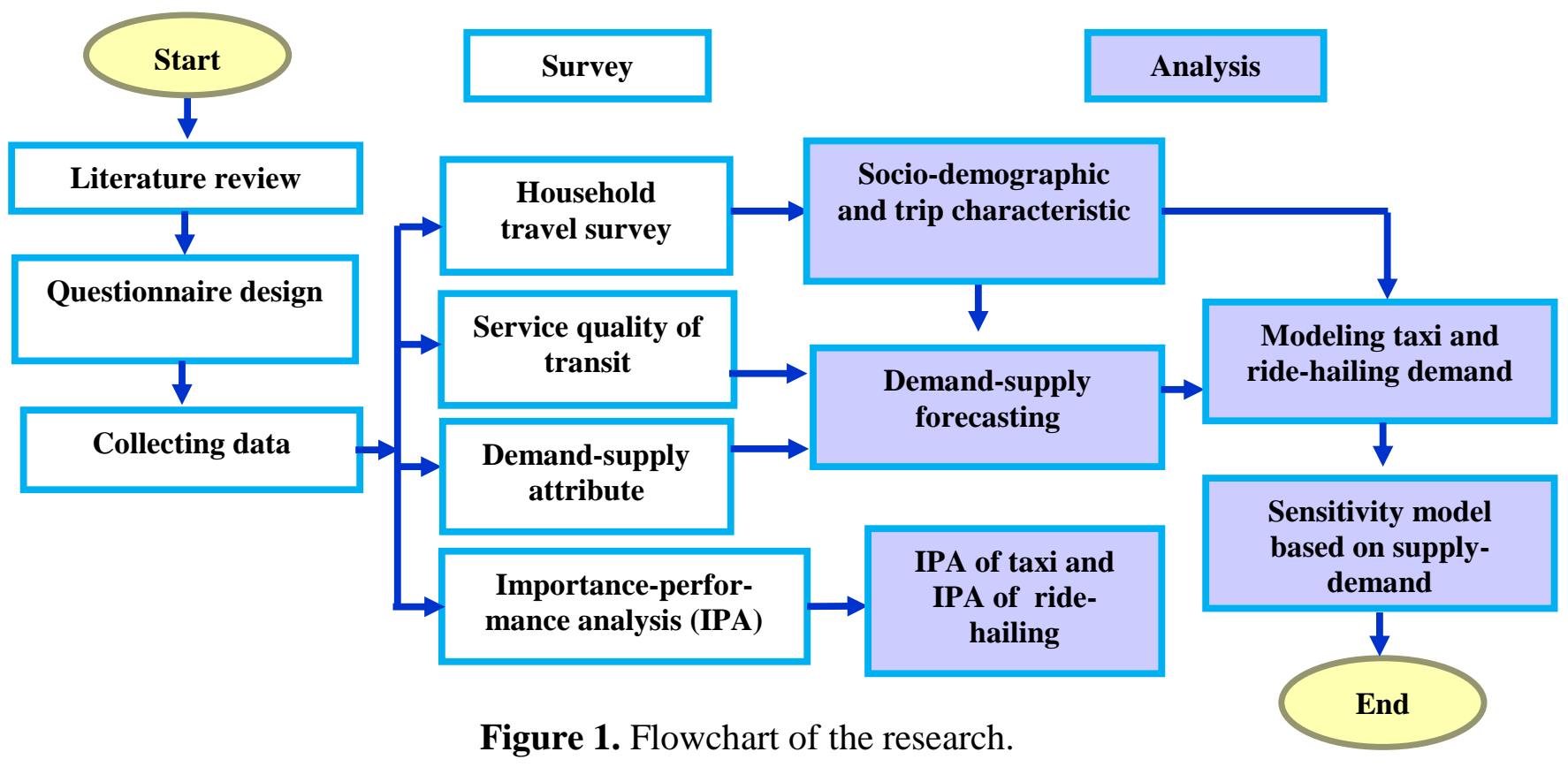

\section{HOUSEHOLD SURVEY}

The study identified socio-demographic and trip characteristics of the sample, a total of 949 respondents, 519 respondents for trip characteristics, 430 respondents for IPA. The sociodemographic includes gender, age, level of education, employment status, monthly income, and respondent's domicile. Trip characteristics include reasons to travel and frequency of use of mode. The study includes a comparison of travel time, travel cost and waiting time by taxi and ride-hailing for specific trips to the origin-destination of trips that are most often done.

\section{IMPORTANCE-PERFORMANCE ANALYSIS}

IPA was introduced by Martilla and James in 1977 as a method for analyzing business strategies. Since its origins, the IPA has been applied in different areas. Data on the service performance and level of importance of taxi is obtained from 220 respondents while for the ride-hailing from 210 respondents. The mean performance rating and mean importance rating 
as a barrier between the quadrants in the Cartesian diagram. There are four possible locations for service attributes, namely quadrant I is concentrated here, quadrant II is to keep up the good work, quadrant III is low priority, or quadrant IV is possible overkill. Evaluation of the level of service for taxis is prepared referring to the Regulation of the Minister of Transportation Republic of Indonesia PM Number 44 of 2019. Evaluation of ride-hailing service is prepared referring to the Regulation of the Minister of Transportation Republic of Indonesia PM Number 17 of 2019. Six indicators studied were security, safety, comfort, affordability, equality, and regularity. For the taxi, six indicators were divided into 39 sub-indicators while for the ride-hailing were divided into 30 sub-indicators. Rating for importance obtained from a five-point Likert scale ranging from very unimportant (1) to very important (5). Rating for performance obtained from a five-point Likert scale ranging from strongly disagree (1) to strongly agree (5) (Rial et al., 2008).

\section{DEMAND-SUPPLY MODEL}

New traffic assignment model based on the concept of shortest path betweenness centrality measure (Sugiyanto et al., 2016), hub and spoke network (Sugiyanto et al., 2020) borrowed from the domain of complex network analysis (Puzis et al., 2013). One of the fields most influenced by this evolving research thrust was the data-driven study of human mobility and its potential application for intelligent transportation systems (Altshuler et al., 2015). Demand of ride-hailing systems was expressed as a function of a variety of demographic, land use, and environmental factors (Gerte et al., 2018). In this research, the demand-supply model uses a calculation variable consisting of seven parameters: number of trips per day, percentage of mode share, average vehicle occupancy factors for taxi and ride-hailing, number of operating, waiting time of passenger, travel time, and waiting of the driver to find users. The calculation of taxi and ride-hailing demand based on the demand-supply model using equation 1.

$$
N=\frac{\sum \text { Trips per day } x M S}{A V O} \times \frac{W T_{\text {pass }} \times W T_{\text {driver }} \times T T}{\sum \text { operating hours per day }}
$$


Where:

$\mathrm{N} \quad=$ transit demand (vehicle units).

$\sum$ Trips per day $=$ the number of trips for passenger travel per day (trips/day).

MS = percentage of mode share for taxi and ride-hailing transport service (\%).

AVO = average vehicle occupancy factors for taxi and ride-hailing (passengers per vehicle)

$\sum$ Operating hours/day $=$ number of operating hours from taxi or ride-hailing per day (hours).

$\mathrm{WT}_{\text {Pass }}=$ waiting time of passengers is the maximum tolerance of waiting time for passengers who order a taxi or ride-hailing (hours).

$\mathrm{WT}_{\text {driver }}=$ waiting time driver to find passengers (hours).

$\mathrm{TT}=$ travel time is distance from origin to destination location divided by speed (hours).

\section{RESULTS AND DISCUSSION}

\section{HOUSEHOLD TRAVEL SURVEY RESULT}

Based on the household travel survey result from 949 respondents, the profile of respondents are at most 37-42 years old, 317 respondents followed by 32-37 years old, 249 respondents. Taxi and ride-hailing users are generally consumers who have worked for several years so that they have the ability to pay for taxis and ride-hailing tariff relatively more expensive than public transport. Male taxi users tend to be more populated than women, $54.50 \%$ versus 45.50\%. Based on the education level the most was at the undergraduate level 465 respondents followed by diploma programs 235 respondents, senior high school 162 respondents. Based on the monthly income of respondents, the most was at IDR7-9 million/month as much as 286 respondents, followed by IDR3-5 million/month, 240 respondents; IDR5-7 million/month, 230 respondents. Most of respondents use motorcycles (29.76\%), followed by ride-hailing $(17.64 \%)$, private cars $(12.20 \%)$, city transport $(11.55 \%)$, taxi $(10.89 \%)$, commuter line $(8.82 \%)$, BRT TransJakarta $(6.66 \%)$. The number of respondents as many as 949 people traveled a total of 10,380 trips in a week. Motorcycles are the most frequently used mode, 3089 trips/week of the total trips of all respondents followed by ride-hailing as much as 1831 trips/week followed by private cars 1266 trips/week. The use of taxis, respectively, is 1130 trips per week. The trip characteristics and reasons to travel are at work as much as 191 
respondents $(36.80 \%)$, followed by others (22.93\%), and business (19.65\%). The sociodemographic and trip characteristics of the sample can be seen in Table 1.

Table 1. Socio-demographic and trip characteristics of the sample $(\mathrm{N}=949)$.

\begin{tabular}{|c|c|c|c|}
\hline Characteristics & Description of variable & Frequency & Percent $(\%)$ \\
\hline \multicolumn{4}{|c|}{ Socio-demographic characteristics } \\
\hline Gender & $\begin{array}{l}\text { Male } \\
\text { Female }\end{array}$ & $\begin{array}{l}517 \\
432\end{array}$ & $\begin{array}{l}54.50 \\
45.50\end{array}$ \\
\hline Age (years old) & $\begin{array}{l}17-22 \\
22-27 \\
27-32 \\
32-37 \\
37-42 \\
42-47 \\
47-52 \\
52-57 \\
57-62 \\
62-67\end{array}$ & $\begin{array}{c}32 \\
43 \\
174 \\
249 \\
317 \\
90 \\
31 \\
7 \\
5 \\
1\end{array}$ & $\begin{array}{c}3.37 \\
4.53 \\
18.34 \\
26.24 \\
33.40 \\
9.48 \\
3.27 \\
0.74 \\
0.53 \\
0.11\end{array}$ \\
\hline Level of education & $\begin{array}{l}\text { Junior high school } \\
\text { Senior high school } \\
\text { Diploma program (D1, D2, D3, and D4) } \\
\text { Undergraduate degree (S1) } \\
\text { Master's and PhD (S2, S3) }\end{array}$ & $\begin{array}{c}8 \\
162 \\
235 \\
465 \\
79\end{array}$ & $\begin{array}{c}0.84 \\
17.07 \\
24.76 \\
49.00 \\
8,32\end{array}$ \\
\hline Employment status & $\begin{array}{l}\text { Student/College student } \\
\text { Government employees/Soldier/Police } \\
\text { Private employees/ BUMN } \\
\text { Teachers/Lecturers/Academic } \\
\text { Entrepreneurship } \\
\text { Housewife } \\
\text { Others }\end{array}$ & $\begin{array}{c}39 \\
95 \\
435 \\
98 \\
84 \\
67 \\
131\end{array}$ & $\begin{array}{c}4.11 \\
10.01 \\
45.84 \\
10.33 \\
8.85 \\
7.06 \\
13.80 \\
\end{array}$ \\
\hline $\begin{array}{l}\text { Monthly income (in } \\
\text { million IDRs) }\end{array}$ & $\begin{array}{l}3-5 \\
5-7 \\
7-9 \\
9-12 \\
12-15 \\
15-20 \\
20-25 \\
25-30 \\
>30 \\
\end{array}$ & $\begin{array}{c}240 \\
230 \\
286 \\
106 \\
44 \\
10 \\
7 \\
4 \\
22 \\
\end{array}$ & $\begin{array}{c}25.29 \\
24.24 \\
30.14 \\
11.17 \\
4.64 \\
1.05 \\
0.74 \\
0.42 \\
2.32 \\
\end{array}$ \\
\hline $\begin{array}{l}\text { Respondent's } \\
\text { domicile }\end{array}$ & $\begin{array}{l}\text { Jakarta Special Province } \\
\text { Bogor City } \\
\text { Bogor Regency } \\
\text { Depok City } \\
\text { Tangerang City } \\
\text { Tangerang Regency } \\
\text { South Tangerang City } \\
\text { Bekasi City } \\
\text { Bekasi Regency }\end{array}$ & $\begin{array}{c}315 \\
37 \\
140 \\
82 \\
71 \\
103 \\
67 \\
71 \\
63 \\
\end{array}$ & $\begin{array}{c}33.19 \\
3.90 \\
14.75 \\
8.64 \\
7.48 \\
10.85 \\
7.06 \\
7.48 \\
6.64 \\
\end{array}$ \\
\hline \multicolumn{4}{|l|}{ Trip characteristics } \\
\hline $\begin{array}{l}\text { Reasons to travel (519 } \\
\text { respondents) }\end{array}$ & $\begin{array}{l}\text { Be at work } \\
\text { Study (to school, campus, university) } \\
\text { Business } \\
\text { Tour (traveling) } \\
\text { Shopping } \\
\text { Family needs } \\
\text { Others }\end{array}$ & $\begin{array}{c}191 \\
8 \\
102 \\
19 \\
38 \\
42 \\
119\end{array}$ & $\begin{array}{c}36.80 \\
1.54 \\
19.65 \\
3.66 \\
7.32 \\
8.09 \\
22.93\end{array}$ \\
\hline $\begin{array}{l}\text { Frequency of use of } \\
\text { mode (trips per week) }\end{array}$ & $\begin{array}{l}\text { Motorcycles } \\
\text { Private cars }\end{array}$ & $\begin{array}{l}3089 \\
1266 \\
\end{array}$ & $\begin{array}{l}29.76 \\
12.20 \\
\end{array}$ \\
\hline
\end{tabular}




\begin{tabular}{|l|l|c|c|}
\hline & Taxi & 1130 & 10.89 \\
& City transport & 1199 & 11.55 \\
& Ride-hailing (Grab, GoCar) & 1831 & 17.64 \\
& Bus Rapid Transit (BRT) Trans Jakarta & 691 & 6.66 \\
& Commuter line & 915 & 8.82 \\
& Light Rail Transit & 81 & 0.78 \\
& Mass Rapid Transit & 178 & 1.71 \\
\hline
\end{tabular}

\section{SERVICE QUALITY OF TRANSIT}

Three parameter in service quality of taxi, ride-hailing and bus include waiting time, travel time and travel costs. A comparison of waiting time, travel time and travel costs for 519 respondents when asked about these trips that are most often done. The average waiting time of taxi is 10.57 minutes and 9.08 minutes for ride-hailing. Average travel time of taxi is 41.54 minutes, 38.87 minutes for ride-hailing, and 59.45 minutes for bus. The average travel cost for taxi is IDR67,842 per trip, IDR56,940 per trip for ride-hailing, and IDR30,697 per trip for bus. Waiting time of ride-hailing users faster $14.08 \%$ than taxi. Travel time with ride-hailing is 2.66 minutes lower than taxi (6.41\% faster than travel time by taxi). In terms of travel costs, using a ride-hailing is cheaper than using a taxi. An average travel cost for ride-hailing is IDR56,940 pertrip, taxi IDR67,842 per trip, and bus IDR30,697 per trip. Average travel costs per trip for ride-hailing is IDR10,901 cheaper than taxi (16.07\%). Average travel cost per trip using the bus is cheaper than ride-hailing and taxis. This result is similar with study Alonso et al. (2018), waiting time is the most important factor for frequent users and journey time is highly valued by almost all users, followed by accessibility and comfort. This result is similar with study Wang and Ross (2019) which discuss about the relationship between taxi and transit in New York. Transit-extending taxi trips have significantly shorter average trip lengths and larger proportions of people paying with cash than other trip types. Amount $15 \%$ of the taxi fleet can serve $98 \%$ of the demand within average waiting time 2.8 minutes (Alonso-Mora et al., 2017).

\section{IMPORTANCE-PERFORMANCE ANALYSIS (IPA)}

\section{A. IPA of taxi}


IPA results of taxi users for 39 service attributes can be seen in Table 2 and plotted into an IPA matrix, as shown in Figure 2. Mean performance rating is 3.18 and mean importance rating is 3.77. Gap analysis is mean importance rating minus (-) mean performance rating.

Table 2. Importance-performance ratings for taxi service of the sample $(\mathrm{N}=220)$.

\begin{tabular}{|c|c|c|c|c|}
\hline $\begin{array}{c}\text { Attribute } \\
\text { code }\end{array}$ & Service attribute & $\begin{array}{c}\text { Mean } \\
\text { importance } \\
\text { rating }\end{array}$ & \begin{tabular}{|c|} 
Mean \\
performance \\
rating
\end{tabular} & $\begin{array}{c}\text { Gap } \\
\text { analy- } \\
\text { sis }\end{array}$ \\
\hline A. & Security (11 attributes) & & & \\
\hline 1 & Availability of driver's identity & 3.80 & 2.91 & 0.89 \\
\hline 2 & Driver's identification card & 3.51 & 3.10 & 0.41 \\
\hline 3 & Customer service & 3.73 & 3.03 & 0.70 \\
\hline 4 & Availability of hazard lights & 3.53 & 2.92 & 0.61 \\
\hline 5 & A set of communication tools & 3.67 & 3.01 & 0.66 \\
\hline 6 & Vehicle identity: taxi trademark & 3.55 & 3.20 & 0.34 \\
\hline 7 & Vehicle identity: serial number & 3.62 & 3.23 & 0.39 \\
\hline 8 & Taxi service complaint telephone number & 3.76 & 3.22 & 0.54 \\
\hline 9 & Door lock buttons & 3.90 & 3.20 & 0.70 \\
\hline 10 & Darkest window film maximum $40 \%$ & 4.08 & 3.66 & 0.42 \\
\hline 11 & Availability of a taxi sign & 3.44 & 3.19 & 0.25 \\
\hline B. & Safety (16 attributes) & & & \\
\hline 12 & Driver physically and mentally healthy & 4.65 & 3.86 & 0.78 \\
\hline 13 & Drivers have competencies & 3.89 & 3.33 & 0.56 \\
\hline 14 & Drivers rest 15 minutes after driving 2 hours. & 3.58 & 3.24 & 0.34 \\
\hline 15 & Availability of first aid kit box & 3.79 & 3.12 & 0.66 \\
\hline 16 & Availability of vehicle speed controllers & 4.00 & 3.10 & 0.89 \\
\hline 17 & The front tires are not allowed to use retread tires & 3.47 & 3.09 & 0.38 \\
\hline 18 & Availability of a glass beater/breaker: hammer on window & 3.99 & 3.02 & 0.97 \\
\hline 19 & Availability of light fire extinguishers & 3.97 & 3.02 & 0.95 \\
\hline 20 & Electrical for audio visual & 3.51 & 3.06 & 0.45 \\
\hline 21 & Safety belt at least 2 points & 3.60 & 3.20 & 0.40 \\
\hline 22 & Global Positioning System/GPS & 4.11 & 3.23 & 0.88 \\
\hline 23 & Flashlight as a lighting aid & 3.30 & 3.04 & 0.27 \\
\hline 24 & Traffic accident insurance & 4.63 & 3.37 & 1.26 \\
\hline 25 & Check vehicle worthiness & 3.49 & 3.15 & 0.34 \\
\hline 26 & Maximum age of vehicle 10 (ten) years & 3.50 & 3.20 & 0.29 \\
\hline 27 & Maintenance facilities (pool) & 3.83 & 3.22 & 0.60 \\
\hline C. & Convenience (5 attributes) & & & \\
\hline 28 & Driver understand area of operation & 3.82 & 3.17 & 0.64 \\
\hline 29 & Driver and passengers can communicate & 3.70 & 3.42 & 0.27 \\
\hline 30 & Driver expected to understand SOP taxi service ethics & 4.10 & 3.37 & 0.73 \\
\hline 31 & Air controllers, temperature in vehicle is $20-22^{\circ} \mathrm{C}$ & 3.98 & 3.30 & 0.68 \\
\hline 32 & Sticker "No Smoking" & 3.44 & 3.18 & 0.26 \\
\hline D. & Affordability (2 attributes) & & & \\
\hline 33 & Taxi service minimum 12 hours all cities & 3.69 & 3.17 & 0.52 \\
\hline 34 & Accessibility makes it easy for passengers to get services & 3.73 & 3.15 & 0.58 \\
\hline E. & Equality ( 2 attributes) & & & \\
\hline 35 & Priority service getting on/off for people with disabilities & 3.88 & 3.07 & 0.81 \\
\hline 36 & Special space in the trunk for wheelchair storage & 3.55 & 3.04 & 0.51 \\
\hline F. & Regularity ( 3 attributes) & & & \\
\hline
\end{tabular}




\begin{tabular}{|c|l|c|c|c|}
\hline 37 & Information basic rates, waiting, distance rates & 3.80 & 3.07 & 0.73 \\
\hline 38 & Taximeter is functioning properly & 3.68 & 3.14 & 0.54 \\
\hline 39 & Time of operation or service of people transport by taxi & 3.75 & 3.13 & 0.62 \\
\hline & Average & $\mathbf{3 . 7 7}$ & $\mathbf{3 . 1 8}$ & $\mathbf{0 . 5 9}$ \\
\hline
\end{tabular}

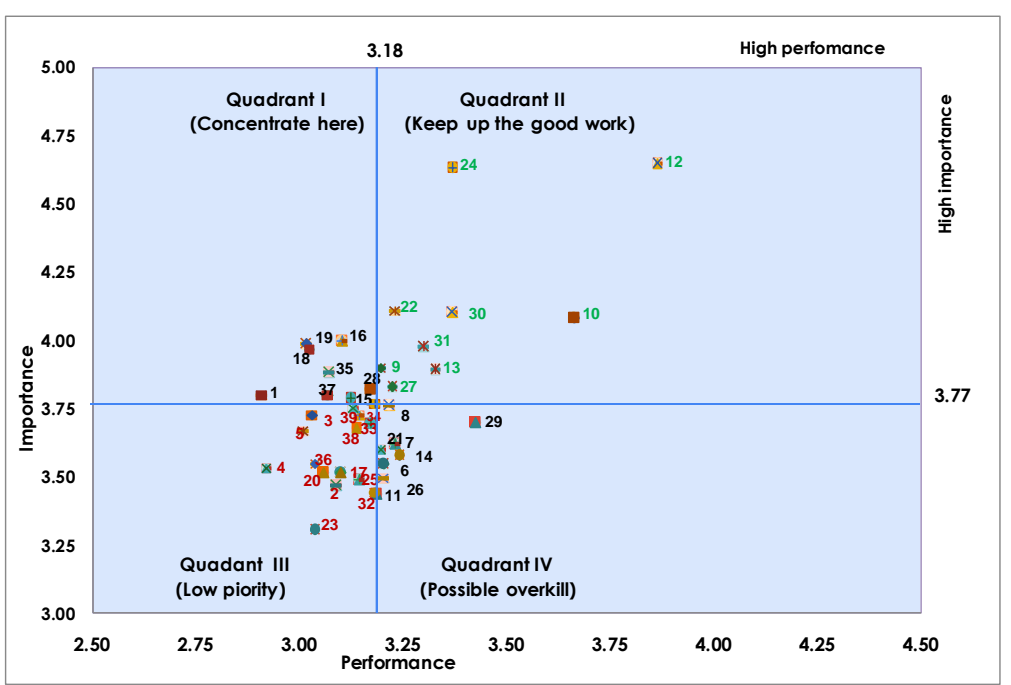

Figure 2. Taxi service levels based on importance-performance analysis.

Based on Figure 2, from 39 service attributes of taxi, 8 attributes are located in quadrant I, namely attribute no.1, 15, 16, 18, 19, 28, 35, and 37. Eight attributes should be given top priority because they are considered very important for taxi users. Nine attributes are located in quadrant II, namely attribute no.9, 10, 12, 13, 22, 24, 27, 30, and 31. These nine attributes must be managed properly by the taxi company. In quadrant III there are 14 attributes, namely attribute no. $2,3,4,5,17,20,23,25,32,33,34,36,38$, and 39 . These fourteen attributes fall into low priority and must be managed and improved in service. In quadrant IV there are 8 attributes, namely attribute no.6, 7, 8, 11, 14, 21, 26, and 29. Eight service attributes can be reduced in service so that taxi companies can save costs.

\section{B. IPA of ride-hailing services}

The IPA results and expectations of ride-hailing users for 30 service attributes can be seen in Table 3 and Figure 3. Mean performance rating is 3.21 and mean importance rating is 3.84 .

Table 3. Importance-performance ratings for ride-hailing service of the sample $(\mathrm{N}=210)$.

\begin{tabular}{|c|l|c|c|c|}
\hline $\begin{array}{c}\text { Attribute } \\
\text { code }\end{array}$ & \multicolumn{1}{|c|}{ Service attribute } & $\begin{array}{c}\text { Mean } \\
\text { importance } \\
\text { rating }\end{array}$ & $\begin{array}{c}\text { Mean } \\
\text { performance } \\
\text { rating }\end{array}$ & $\begin{array}{c}\text { Gap } \\
\text { analysis }\end{array}$ \\
\hline A. & Security (4 attributes) & & & \\
\hline 1 & Identity of service users who orders & 3.82 & 2.87 & 0.95 \\
\hline 2 & Availability of driver's identity & 3.71 & 3.02 & 0.69 \\
\hline
\end{tabular}




\begin{tabular}{|c|c|c|c|c|}
\hline 3 & Security disturbance information & 4.11 & 3.19 & 0.93 \\
\hline 4 & Darkest window film maximum $40 \%$ & 4.28 & 3.51 & 0.77 \\
\hline B. & Safety (11 attributes) & & & \\
\hline 5 & Driver physically and mentally healthy & 4.66 & 3.73 & 0.93 \\
\hline 6 & Driver has the competence & 4.38 & 3.44 & 0.94 \\
\hline 7 & Maximum working for driver is 8 hours & 3.42 & 3.18 & 0.23 \\
\hline 8 & Drivers rest 30 minutes after driving vehicle every 4 hours & 3.56 & 3.14 & 0.42 \\
\hline 9 & Availability of flashlights or lighting aids & 3.38 & 3.03 & 0.34 \\
\hline 10 & Availability of first aid kit in case of accident & 4.26 & 3.31 & 0.95 \\
\hline 11 & Availability of a light fire extinguisher in the vehicle & 4.22 & 3.19 & 1.03 \\
\hline 12 & Availability of safety belts at least 2 points & 3.53 & 3.20 & 0.33 \\
\hline 13 & Checks the vehicle to be operated & 3.47 & 3.13 & 0.33 \\
\hline 14 & Traffic accident insurance & 4.37 & 3.31 & 1.06 \\
\hline 15 & Maximum age of vehicle is 5 years & 3.46 & 3.12 & 0.33 \\
\hline C. & Convenience (10 attributes) & & & \\
\hline 16 & Number of passengers according to the carrying capacity & 3.55 & 3.20 & 0.35 \\
\hline 17 & Driver doesn't bring other than passenger who book & 3.77 & 3.19 & 0.58 \\
\hline 18 & Availability of an $\mathrm{AC}$, the highest air temperature is $25^{\circ} \mathrm{C}$ & 3.86 & 3.10 & 0.75 \\
\hline 19 & Availability of baggage & 3.50 & 3.38 & 0.12 \\
\hline 20 & Availability of cleanliness facilities & 4.05 & 3.30 & 0.75 \\
\hline 21 & The driver wears modest clothing & 4.28 & 3.48 & 0.80 \\
\hline 22 & Driver behavior is friendly and polite & 4.29 & 3.42 & 0.87 \\
\hline 23 & Audio visual facilities in passenger room & 3.56 & 3.19 & 0.37 \\
\hline 24 & Availability of cell phone battery charging facilities. & 3.48 & 3.05 & 0.43 \\
\hline 25 & Sticker "No Smoking" & 3.48 & 3.10 & 0.38 \\
\hline D. & Affordability ( 2 attributes) & & & \\
\hline 26 & Accessibility: services according to the route listed & 3.72 & 3.15 & 0.57 \\
\hline 27 & Applying rates according to upper and lower limit rate & 3.76 & 3.16 & 0.60 \\
\hline E. & Equality ( 2 attributes) & & & \\
\hline 28 & Priority service getting on or off for disabilities. & 3.71 & 3.07 & 0.64 \\
\hline 29 & Accessibility facilities for people who have disabilities. & 3.73 & 3.05 & 0.68 \\
\hline F. & Regularity (1 attribute) & & & \\
\hline 30 & Service time according to the order & 3.73 & 3.12 & 0.60 \\
\hline & Average & 3.84 & 3.21 & $\mathbf{0 . 6 3}$ \\
\hline
\end{tabular}

Based on Figure 3, from 30 ride-hailing service attributes, 3 attributes are located in quadrant I,

namely attribute no.3, 11, and 18 . Three attributes should be given top priority by service providers because they are considered very important for ride-hailing users. Eight attributes are located in quadrant II, namely attribute no.4, 5, 6, 10, 14, 20, 21, and 22. These eight attributes should continue to be properly managed by a ride-hailing company. In quadrant III there are 18 attributes, namely attribute no.1, 2, 7, 8, 9, 12, 13, 15, 16, 17, 23, 24, 25, 26, 27, 28, 29, and 30. The eighteen attributes fall into low priority and must be managed and improved in service. In quadrant IV, only one attribute no. 19 can be reduced to save operation costs. 


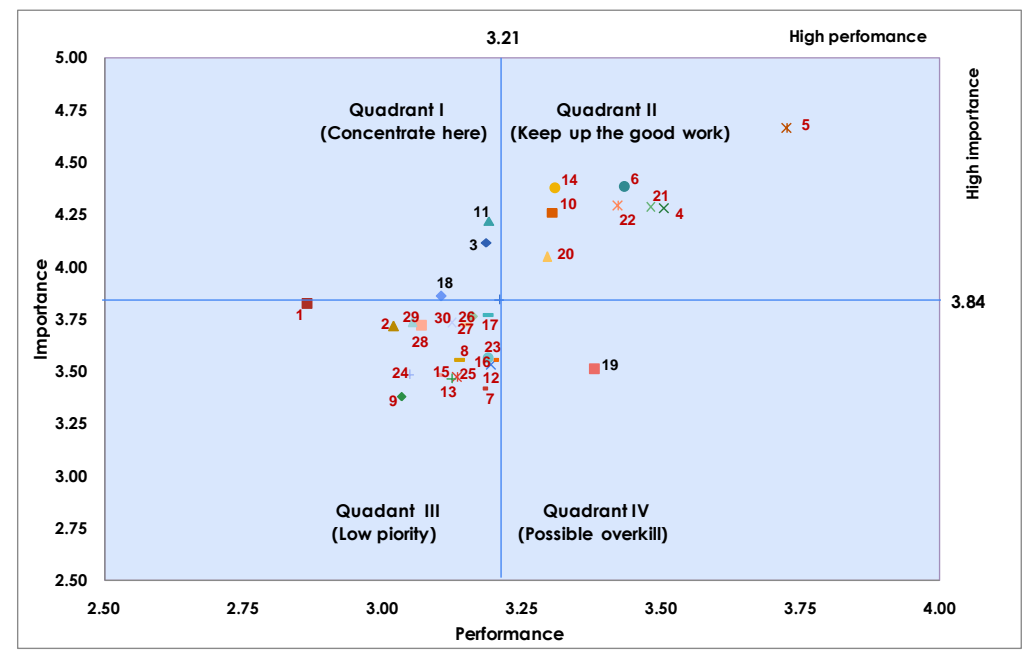

Figure 3. Ride-hailing service levels based on importance-performance analysis.

\section{DEMAND-SUPPLY FORECASTING}

Seven parameters are used to forecast taxi and ride-hailing service demand. Each parameter value based on transportation user survey in the Jakarta Greater area in July 2020 is as follows.

1. The number of trips per day based on data from the origin-destinations survey of national transportation for passengers in Indonesia in 2018. The number of trips for passengers in the Jakarta Greater area in 2018 was 62,397,792 trips per day (Ministry of Transportation, 2018). Using the assumption of a growth rate of $5 \%$ per year, it is estimated that trips per day for all transportation modes in 2019 will be 65,517,682 trips/day.

2. Percentage of mode share for taxi and ride-hailing in the Jakarta Greater area is $1.75 \%$.

3. Average vehicle occupancy factors are assumed to be filled with 2 passengers per vehicle.

4. Number of operating hours per day based on the survey varies from 12-24 hours. In this case, taking into account the traffic safety and driver physical condition, operating hours are 16 hours with 2 drivers (each driver works eight hours per day).

5. Waiting time of passengers is the time tolerance for customer waiting. Using data from the survey results, the average user getting a taxi is 10.57 minutes and ride-hailing service is 9.08 minutes. The number of taxis in the Jakarta Greater area in July 2020 was 17,268 units and ride-hailing was 33,133 units. The average waiting time of passengers for taxi and ridehailing service is calculated based on the comparison of the number of fleets and waiting times for taxis and ride-hailing service, obtained at 0.1598 hour. 
6. Average travel time by taxi and ride-hailing is 38.87 minutes for ride-hailing and 41.54 minutes for taxi. Average travel time for taxi and ride-hailing is 0.6631 hour.

7. Waiting time driver. The time it takes to get passengers from the driver's side is determined based on the results of an interview survey of taxi and ride hailing companies. The information obtained is the number of vehicle trips per day and operating time per day. Number of trips per day varies with the range of 7-8 trips/day. Number of operating hours per day is 16 hours and the number of trips is 8 trips/day. Average waiting time from passengers is 9.591 minutes and the average travel time for taxi and ride-hailing service users is 39.785 minutes. Waiting time for the driver to find a passenger is 1.1770 hours.

Based on the value of each parameter, using equation 1, calculations of the taxi and ridehailing demand in the Jakarta Greater area is 71,660 vehicles. Significant variables in the calculation are the number of operating hours per day, number of trips per day, waiting time and travel time. The fares of Transmilenio was reduced and implemented fare discrimination between peak hours and off-peak hours to balance the daily demand distribution in the BRT system (Guzman et al., 2018). Çam and Sezen (2020) using vehicle routing problems to minimize the total idle time. Another study by Giri and Dey (2020) using a closed-loop supply chain with stochastic demand. Zhang et al. (2019) using a dual-channel retailer to identify whether the strategy is beneficial for improving retailer's market share.

\section{MODELING TAXI AND RIDE-HAILING DEMAND}

In this research, the demand of taxis and ride-hailing services is forecast using the demandsupply model. There are seven factors that influence the demand on taxi and ride-hailing: number of trips per day, average vehicle occupancy factors, percentage of mode share, number of operating hours per day, waiting time of passengers, travel time, and waiting for the driver to find users. As mentioned by Gerte et al. (2018), the demand of ride-hailing systems was expressed as a function of a variety of demographic, environmental factors, and land use. The demand of taxis and ride-hailing service is compared with the number of transit services in July 
2020. The number of taxis in the Jakarta Greater area in July was 17,268 vehicle units and the number of ride-hailing was 33,133 vehicles, a total 50,401 vehicles. Percentage of mode share for taxis and ride-hailing is variation from 1.1 to $2 \%$ to know the sensitivity of this variable. If the number percentage of mode share for taxi and ride-hailing services is $1.1 \%$, the number of taxi and ride-hailing services is 45,043 vehicles. Percentage of mode share $1.2 \%$ gets the number of taxi and ride-hailing 49,138 vehicle units. For the value percentage of mode share more than $1.3 \%$, the forecasting demand of taxi and ride-hailing services is more than the number in existing condition (50,401 vehicles). Demand of taxi and ride-hailing service based on percentage of mode share variation from 1.1 to $2.0 \%$ is shown in Figure 4.

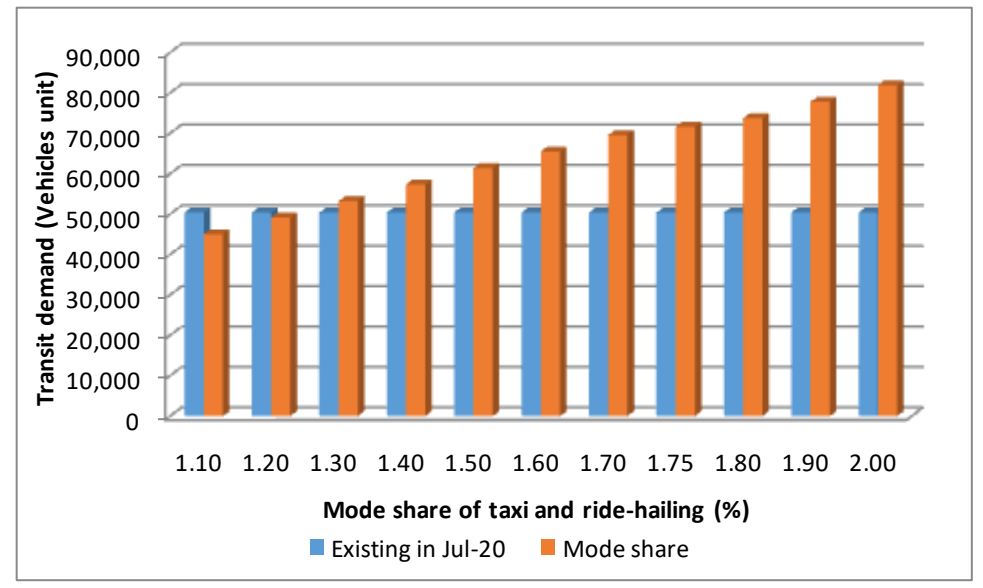

Figure 4. Transit demand based on percentage of mode share variation from 1.1 to $2.0 \%$.

Several determinants of ride-hailing transport, including built environment, socio-economic attributes (Sugiyanto, 2018), trip characteristics (Wang \& Mu, 2018), attitudinal factors (Alemi et al., 2018), and lifestyle (Lavieri \& Bhat, 2019). Gender, age, and education level as the key socio-demographic characteristics in modeling taxi demand (Zhang et al., 2016). Anti-shared mobility, cost-effectiveness, trip security, and technology-oriented riders have a significant impact on ride-hailing trips (Ghasrodashti \& Hamidi, 2019). Schreffler (2018) studies quantify the level of satisfaction perceived by taxi users and how users choose their transportation mode. Wang (2017) using the gap analysis between rider demands and driver supply in a given time period. Accurate prediction of ride-hailing demand helps companies and drivers make informed decisions to reduce traffic congestion, vehicle miles traveled (Hennessy \& 
Wiesenthal, 1999), higher propensity for accidents (Sugiyanto et al., 2019). In major cities in the United States, $21 \%$ of adults use ride-hailing services (Clewlow \& Mishra, 2017). Based on the International Association of Public Transport, an average of 1 taxi unit serves 291 people. The highest in Izmir, 1 taxi unit serves 1232 people and the lowest is in New York, 1 taxi serves only 108 people (Yildizgoz, 2018). The population of the Jakarta Greater area is $31,679,179$ people. With the number of taxis 17,268 vehicles and ride-hailing 33,133 vehicles, total 50,401, every 1000 residents are served by 1.59 taxis or 1 taxi unit serves 629 people.

\section{CONCLUSIONS AND FURTHER RESEARCH}

This study identifies the service quality of transit and forecasting demand of taxis and ridehailing using the demand-supply model. Through this study, the ride-hailing service is better than conventional taxis based on waiting time, travel time, and travel cost. Waiting time of ride-hailing is $14.08 \%$ faster than taxi, travel time ride-hailing is $6.41 \%$ faster than taxi, and travel costs per trip ride-hailing is $16.07 \%$ cheaper than taxi. Average travel cost per trip using a bus is cheaper than ride-hailing and taxis. Factors that influence taxi and ride-hailing service demand are the number of operating hours per day, number of trips per day, waiting time, and travel time. The forecasting of taxi and ride-hailing demand in the Jakarta Greater area based on demand-supply model is 71,660 vehicles.

The further research is modeling taxi and ride-hailing demand using global positioning system data and transit schedule information and forecasting transit demand using dynamic models.

\section{ACKNOWLEDGEMENTS}

"This research is supported by Jenderal Soedirman University". "The authors fully acknowledged the Ministry of Education, Culture, Research and Technology Republic of Indonesia and Jenderal Soedirman University for the approved fund". 


\section{REFERENCES}

Alemi, F., Circella, G., Handy, S. \& Mokhtarian, P. 2018. What influences travelers to use Uber? Exploring the factors affecting the adoption of on-demand ride services in California. Travel Behaviour and Society 13: 88-104.

Alonso-Mora, J., Samaranayake, S., Wallar, A., Frazzoli, E. \& Rus, D. 2017. On-demand highcapacity ride-sharing via dynamic trip-vehicle assignment. Proceedings of the National Academy of Sciences 114(3): 462-7.

Alonso, B., Barreda, R., dell'Olio, L. \& Ibeas, A. 2018. Modeling user perception of taxi service quality. Transport Policy 63: 157-64.

Altshuler, Y., Puzis, R., Elovici, Y., Bekhor, S. \& Pentland, A.S. 2015. On the rationality and optimality of transportation networks defense: a network centrality approach. Securing Transportation Systems chapter 3: 35-63.

Brodeur, A. \& Nield, K. 2018. An empirical analysis of taxi, Lyft and Uber rides: Evidence from weather shocks in NYC. Journal of Economic Behavior and Organization 152: 1-16.

Çam, O.N. \& Sezen, H.K. 2020. The formulation of a linear programming model for the vehicle routing problem in order to minimize idle time. Decision Making: Applications in Management and Engineering 3(1): 22-9.

Chang, H.W., Tai, Y.C. \& Hsu, J.Y.J. 2010. Context-aware taxi demand hotspots prediction. International Journal of Business Intelligence and Data Mining 5(1): 3-18.

Circella, G. \& Mokhtarian, P.L. 2017. Impacts of information and communication technology. The Geography of Urban Transportation, Guilford Press: New York: 1-86.

Clewlow, R.R. \& Mishra, G.S. 2017. The adoption, utilization, and impacts of ride-hailing in the United States. University of California, Institute of Transportation Studies.

Csiszár, C. \& Földes, D. 2015. Analysis and modeling methods of urban integrated information system of transportation. Proceedings of the 2015 IEEE Smart Cities Symposium Prague, Czech: 1-10.

Gerte, R., Konduri, K.C. \& Eluru, N. 2018. Is there a limit to adoption of dynamic ridesharing systems? Evidence from analysis of Uber demand data from New York City. Transportation Research Record 42: 127-36.

Ghasrodashti, R.E. \& Hamidi, S. 2019. Individuals' demand for ride-hailing services: Investigating the combined effects of attitudinal factors, land use, and travel attributes on demand for app-based taxis in Tehran, Iran. Sustainability 11(20): 5755-73.

Giri, B.C., \& Dey, S. 2020. Game theoretic models for a closed-loop supply chain with stochastic demand and backup supplier under dual channel recycling. Decision Making: Applications in Management and Engineering 3(1): 108-25.

Gong, Y., Fang, B., Zhang, S. \& Zhang, J. 2016. Predict New York City taxi demand, NYC Data Science Academy.

Gonzales, E.J., Yang, C., Morgul, E.F. \& Ozbay, K. 2014. Modeling taxi demand with GPS data from taxis and transit. Mineta National Transit Research Consortium MNTRC Report 12-16, College of Business San Jose State University, USA. p. 1-68.

Guzman, L.A., Moncada, C.A. \& Gómez, S. 2018. Fare discrimination and daily demand distribution in the BRT system in Bogotá. Journal of Public Transportation 10: 191-216. 
Hall, J.D., Palsson, C. \&, Price, J. 2018. Is Uber a substitute or complement for public transit? Journal of Urban Economics 108: 36-50.

Hennessy, D.A. \& Wiesenthal, D.L. 1999. Traffic congestion, driver stress, and driver aggression. Aggressive Behavior 25(6): 409-23.

Kim, J., Rasouli, S. \& Timmermans, H. 2017. Satisfaction and uncertainty in car-sharing decisions: An integration of hybrid choice and random regret-based models. Transportation Research Part A: Policy and Practice 95: 13-33.

Lavieri, P.S. \& Bhat, C.R. 2019. Investigating objective and subjective factors influencing the adoption, frequency, and characteristics of ride-hailing trips. Transportation Research Part C: Emerging Technologies 105: 100-25.

Martilla, J.A. \& James, J.C. 1977. Importance-performance analysis. J. Marketing 41(1):77-9

Ministry of Transportation. 2018. Badan Penelitian dan Pengembangan Kemenhub. Survei Asal Tujuan Transportasi Nasional Orang Tahun 2018 Penumpang Berbasis Big Data.

Ministry of Transportation. 2019. Peraturan Menteri Perhubungan No.PM 44 Tahun 2019 tentang Perubahan Kedua atas No.PM 46 Tahun 2014 tentang Standar Pelayanan Minimal Angkutan Orang dengan Kendaraan Bermotor Umum Tidak Dalam Trayek.

Ministry of Transportation Republic of Indonesia. 2019. Peraturan Menteri Perhubungan Republik Indonesia Nomor PM 17 Tahun 2019 tentang Perubahan atas Peraturan Menteri Perhubungan No. PM 118 tahun 2018 tentang Penyelenggaraan Angkutan Sewa Khusus.

Moreira-Matias, L., Gama, J., Ferreira, M. \& Damas, L. 2012. A predictive model for the passenger demand on a taxi network. $15^{\text {th }}$ International IEEE Conference on Intelligent Transportation Systems: 1014-9.

Oviedo, D., Granada, I. \& Jaramillo, D.P. 2020. Ride sourcing and travel demand: Potential effects of transportation network companies in Bogotá. Sustainability 12(5): 1732-47.

Puzis, R., Altshuler, Y., Elovici, Y., Bekhor, S., Shiftan, Y. \& Pentland, A. 2013. Augmented betweenness centrality for environmentally-aware traffic monitoring in transportation networks. Journal of Intelligent Transportation Systems Journal 17(1): 91-105

Rayle, L., Dai, D., Chan, N., Cervero, R. \& Shaheen, S. 2016. Just a better taxi? A survey-based comparison of taxis, transit and ride sourcing services in San Francisco. Transport Policy 45:168-78.

Rial, A., Rial, J., Varela, J. \& Real, E. 2008. An application of importance-performance analysis to the management of sport centres. Managing Leisure 13(3-4): 179-88.

Schreffler, E. 2018. Better integrating travel choices into future urban mobility systems: The day the highways stood still. Journal of Public Transportation 21(1): 82-91.

Sugiyanto, G., Santosa, P.B., Wibowo, A., Santi, M.Y. 2016. Hub and spoke airport networks in Indonesia based on Herfindahl-Hirschmann Index (HHI). Journal of Engineering and Applied Sciences 11(8): 1804-10.

Sugiyanto, G. 2018. The effect of congestion pricing scheme on the generalized cost and speed of motorcycle. Walailak Journal of Science and Technology 15(1): 95-106.

Sugiyanto, G., Jajang, \& Santi, M.Y. 2019. The impact of lowering speed limit on mobility and the environment. AIP Conference Proceeding 2094(1) 020019: 1-8.

Sugiyanto, G., Santosa, P.B. \& Santi, M.Y. 2020. Hub and spoke airport networks in Sulawesi Island, Indonesia based on freight ratio. ARPN Journal of Engineering Applied Sciences 15(10): 1101-10. 
Wang, F. \& Ross, C.L. 2019. New potential for multimodal connection: Exploring the relationship between taxi and transit in New York City. Transportation 46: 1051-72.

Wang, M. \& Mu, L. 2018. Spatial disparities of Uber accessibility: An exploratory analysis in Atlanta, USA. Computers, Environment and Urban Systems 67: 169-75.

Wang, R. 2017. Supply-demand forecasting for a ride-hailing systems. [thesis]. Master in Transportation Science University of California Irvine: 1-30.

Yildizgoz, K. 2018. Panaroma of taxi transport worldwide Results of UITP Taxi Benchmarking Study. International Association of Public Transport: 1-29.

Zhang, P., He, Y., \& Zhao, X. 2019. Preorder-online, pickup-in-store strategy for a dual-channel retailer. Transportation Research Part E: Logistics and Transportation Review 122: 27-47.

Zhang, Y., Guo, H., Li, C., Wang, W., Jiang, X. \& Liu, Y. 2016. Which one is more attractive to traveler, taxi or tailored taxi? An empirical study in China. Procedia Engineering 137: 867-75. 